\title{
Storm water Management in the context of Climate Change and Rapid Urbanization: A case of Tokyo Metropolitan Binaya Kumar Mishra ${ }^{1}$ \\ ${ }^{1}$ Professor, School of Engineering, Pokhara University, Nepal \\ Email: bkmishra@pu.edu.np
}

\begin{abstract}
Groundwater table depletion and increasing flood events can be easily realized in urban areas. It is necessary to improve existing storm water management systems for good quality water environment and reduced hydro-meteorological disasters while preserving our natural/pristine environment in a sustainable manner. This can be achieved through optimal collection, infiltration and storage of storm water. The need of sustainable storm water management is desired and optimal capture measure is explored in this paper. This paper provides a review of storm water management in urbanization and climate change context with a case study of Tokyo Metropolitan, Japan which could be helpful in mitigating the dual problems of groundwater depletion and flood events. This paper presents the overview of storm water run-off management in order to guide future storm water management policies. Also, the effects of different onsite facilities from water harvesting, reuse, ponds and infiltration are explored to establish adaptation strategies that restore water cycle and reduce climate change induced flood and water scarcity.
\end{abstract}

Key words: Climate Change adaptation, Storm water management, Urban water security, Water infrastructure

\section{Background}

It is now well accepted that the conventional urban water management approach is highly unsuited to addressing current and future sustainability issues (Ashley et al., 2005). Climate change and haphazard urbanization have led excess runoff, pollutant loads and pressure on existing systems. In a natural environment the small percentage of precipitation becomes surface runoff, but as the urbanization is growing and the development is expanding, the percentage of storm water also increased abruptly (Figure 1). The surface water runoff is created when pervious or impervious surfaces are saturated from precipitation or snow melt (Durrans, 2003). Pervious surface areas absorb the water naturally to the saturation point and the amount of rainwater runs off and travel via gravity to the nearest stream. 


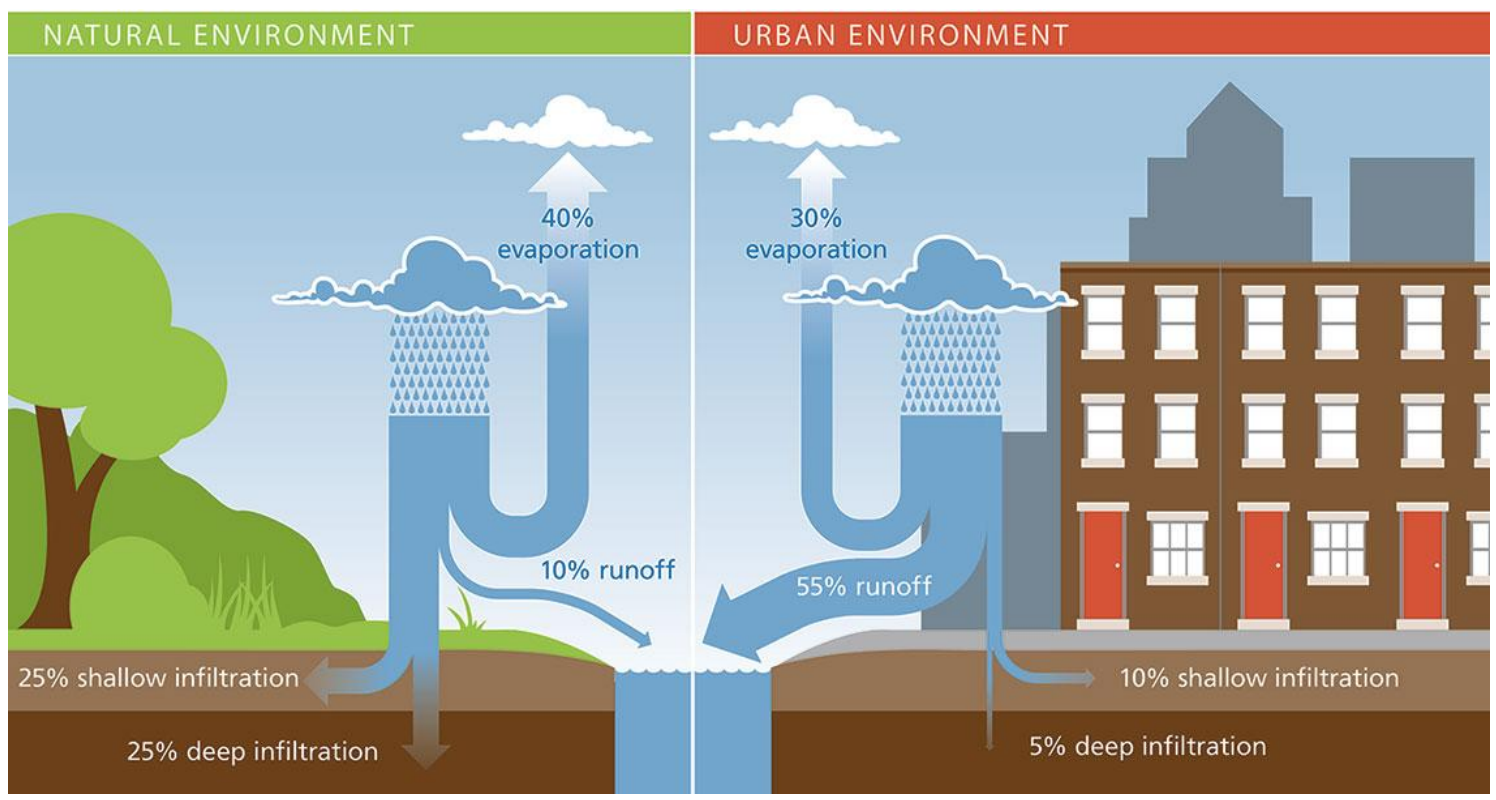

Figure 1: The difference in the absorption and surface run-off in natural and urban environment (Source: SMDM, 2018)

In the urban environment the impervious surfaces which covers the natural environment over the ground, the pattern of hydrological process of surface water runoff become more unnatural, causing damage to infrastructure and the impairment of receiving waters by pollutants (Ragab at el., 2003). There is need for storm water run-off management capture and transportation systems developed as a result of human experiences with various challenges due to destructive floods.

The sustainable storm water run-off management target to understand the changes in the urban landscape, where addition of vegetation is not widely seen and aim to devise approaches to limiting certain undesirable effects, and take advantage of the newly offered opportunities (Huang, 2007). A sustainable storm water system is not a system to deal with the runoff problems and avoiding unwanted content in the water, but it is the system to increase the potential usability as a water resource in society (Sundberg et al., 2004). Stormwater capture and drainage may not only be considered as systems to divert undesired water from urban areas, but also as a valuable element for landscaping the surrounding of buildings and roads (Boller et al, 2004).In general, to control surface runoff, the flood control agencies build large centralized facilities, such as culverts, detention basins and sometimes re-engineered natural hydrologic features such as paving the cities, river channels to quickly convey runoff to receiving water bodies. These large-scale facilities are needed to handle the massive amounts of runoff generated by the largest storm events that would be impractical to handle on a decentralized parcel-by-parcel basis with small-scale infiltration devices. The current trend is toward a more overall integrated approach to manage the storm water runoff 
as an integrated system of preventive and control practices is used to accomplish storm water management goals. The first principle is to minimize the generation of runoff and pollutants through a variety of techniques and second principle is to manage runoff and its pollutants to minimize its impacts on humans and the environment in a cost effective manner (EPA, 2007).

Utilization of remote sensing and Geographic Information System (GIS) technology in the storm water management is constantly evolving and commonly used GIS technologies are utilized to help the decision makers to find out the most efficient ways to manage storm water, by selecting the capture measures and evaluating optimal way to capture the urban runoff. There will frequently be decisions made in storm water management that reflect economic, political, social, and aesthetic components that may not always be easily incorporated into a GIS analyses and modeling system. Important aspect of community attitudes is also considered in this study, as these attitudes are influenced by a range of factors including knowledge of urban water problem, frequency and water restrictions, familiarity with use of alternative water sources and either positive or negative support from water authorities, government agencies and researchers (Mitchell et al. 2006a, Dolnicar et al. 2009).Earlier, storm water management in Japan was largely aimed to control stream flow for municipal and commercial use while preventing water related disaster in the city. However, in recent years, storm water management policies were shifted from exclusive use of structural approaches to using a combination of structural and non-structural approaches. Japanese flood management began with the policies implemented during the 300BC in the Yayoi period. In 1960, there was an effort to move away from concrete dams and focus instead on the hydrologic function of green dams, which rely on the flow retarding capacity of forests to reduce flood risk (Takara et al., 2004; Calder, 2007).The country is focusing to reduce surface runoff by increasing the storm water percolation rates through enhanced infiltration.

In this paper, storm water runoff management and latest practices in use has been reviewed, to achieve the urban water security. The paper explored the different characteristics in the storm water run-off management policies and strategies adopted by Japan. Additionally, this paper provides the detailed assessment to assist the future policy makers and researchers in the field of storm water run-off management planning, to understand the significance and emerging role of remote sensing and GIS in designing the optimal surface run-off measures under the specter of future extreme events and climate change.

\section{Stormwater Run-off in Changing Context}

In the changing context of urbanization and climate and various shifting management policies, the storm water runoff is impacted severely. As it is well known fact that the 
urbanization alters watershed hydrology as land becomes more and more covered with surfaces impervious to rain, water is redirected from groundwater recharge and climate change is altering evapotranspiration rate to storm water run-off, and as the area of impervious cover increases, so does the volume and rate of runoff and weak regulatory policies worsening the situation (Schueler, 1994). Pollutants accumulate on impervious surfaces, and the increased runoff with urbanization is a leading cause of nonpoint source pollution. Sediment, chemicals, bacteria, viruses, and other pollutants are carried into receiving water bodies, resulting in degraded water quality. Blair et al. (2010), tested and analyzed more than thirteen watershed locations in the coastal Carolina and developed a method to model the impacts of urbanization and climate change on storm water runoff, which was based on the modeling methods of Natural Resources Conservation Services (NRCS) and United States Department of Agriculture (USDA) and generated the hydrographs of rate and time. In Figure 2, hydrograph explains different levels of urbanization impact on rainfall percentage and also analyzing the climate change impacts on urban, suburban and forested watersheds.

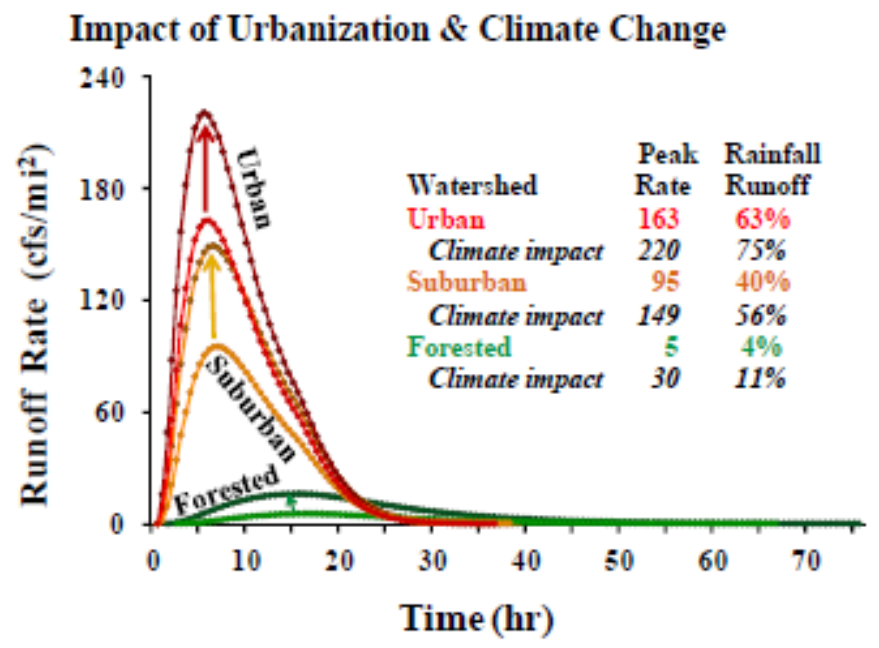

Figure 2: Hydrographs showing runoff from 3 test watersheds at different levels of development (based on impervious cover). Y-axis shows runoff rate, and $\mathrm{X}$-axis shows time. Hydrograph here illustrated the impact of urbanization and climate change on runoff. Climate impact curves are based on 24-hour 5-inch rain, semi-saturated runoff conditions. (Blair, et al., 2010).

Under urbanization, climate change and management policy changes context, the storm water discharge is versatile, and arises from storm water volume quantity and quality. All the above mentioned factors affect the storm water, which is precipitation such as rain, sleet, or melting snow. In a natural setting, only very small percentage of precipitation becomes surface runoff, but as the urbanization is growing and the development expanding, this percentage of storm water is increasing abruptly. This runoff normally flows into the nearest stream or river 
and increase the percentage of water in the system and if it is polluted it can lead to disastrous situations and various kind of pollution.

\section{Methodology for the assessment of optimal storm water management}

The detail methodology of assessment of optimal storm water management in this study is presented in Figure 3. The study provides an overview of environmental impacts of surface water run-off and implications from the issue and associates the need of strong surface runoff management measures in order to achieve sustainable use of water resources in urban environment. The studies analyzed the impact of storm water runoff in changing context, under changing environment, in which various researches compared and evaluated the findings under context of climate change, urbanization and regulation of storm water management. With the help of hydrographs, it was easy to understand the major negative impact on surface runoff and nearby water bodies. After analysis of storm water runoff under various context, assessment of storm water run-off management practices include understanding of historical trends, the role of remote sensing and geographic information system technology in identifying and deciding storm water capture measures and analysis of its effectiveness. Based on numerical simulation modeling and economic aspect of storm water runoff management measures, the current scenarios and optimal future strategies are assessed. This is followed by the case studies to analyze the current practicing storm water run-off management in the study area and compared the advantages and disadvantages of policies with respect to historical, engineering and hydrologic dimensions. This study also presents the discussion on the various Best Management Practices (BMP's) and Low Impact Development (LID) management practices. Finally, the recommendation for the policy makers in order to design the optimal storm water runoff measures and management were suggested. First, the general research papers, online material, historical analysis of storm water management were reviewed. Detailed information on historical trends and role of GIS and remote sensing studied and compared. 


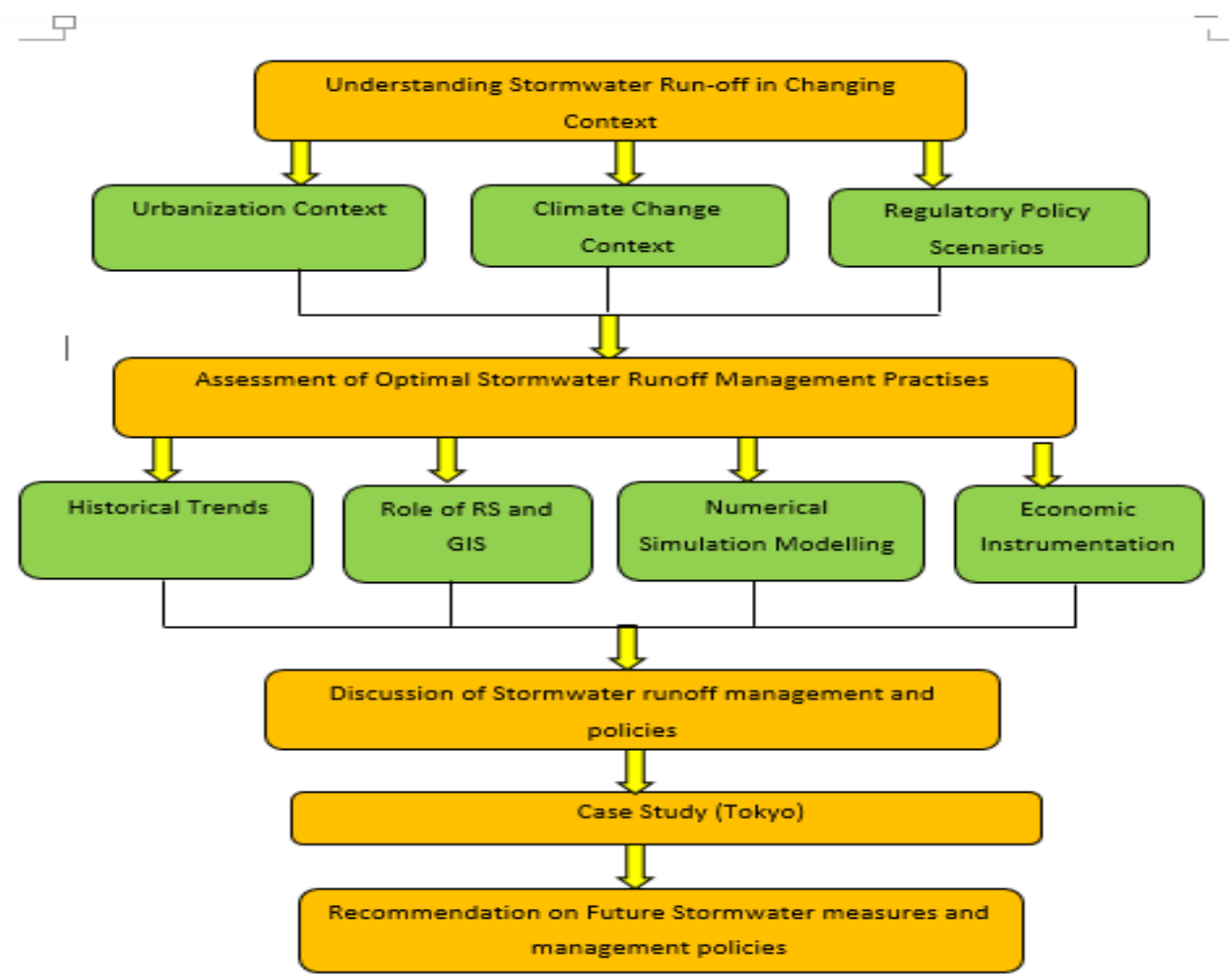

Figure 3: Process of the methodology for the assessment of storm water runoff management measures to attain the urban water security.

\section{Case Study (Tokyo)}

The cities in Japan and several other countries are eagerly applying storm water infiltration as storm water runoff management measure but still many of local governments of the cities are hesitating to ask people to install soak ways and small detention basins in private property. A case of Tokyo is discussed here where it appeared that storm water infiltration is widely accepted and implemented. Along building storm water infiltration measures, government is also focusing on building massive sewerages to capture and transport storm water out of the city in case of flood situation or emergency to protect city from disasters.

Tokyo is capital city of Japan, with total area of $2188 \mathrm{~km}^{2}$, situated at $35^{\circ}$ North and $139^{\circ}$ East. The annual precipitation in Tokyo is around $1530 \mathrm{~mm}$ and population is highest in the world in any city. The city also suffered from serious flood problems in the past for a very long time and storm water runoff is always been serious concern for the local government. As showed in Figure 4, land use/cover maps of Tokyo showed the urbanization effect in the city. Tokyo is focusing on structural and non-structural measure for storm water runoff control. On one side Tokyo is investing and building huge tunnels like G-cans (Figure 5) but at the same time local government encouraging resident to use other BMPs and ground water infiltration system. 


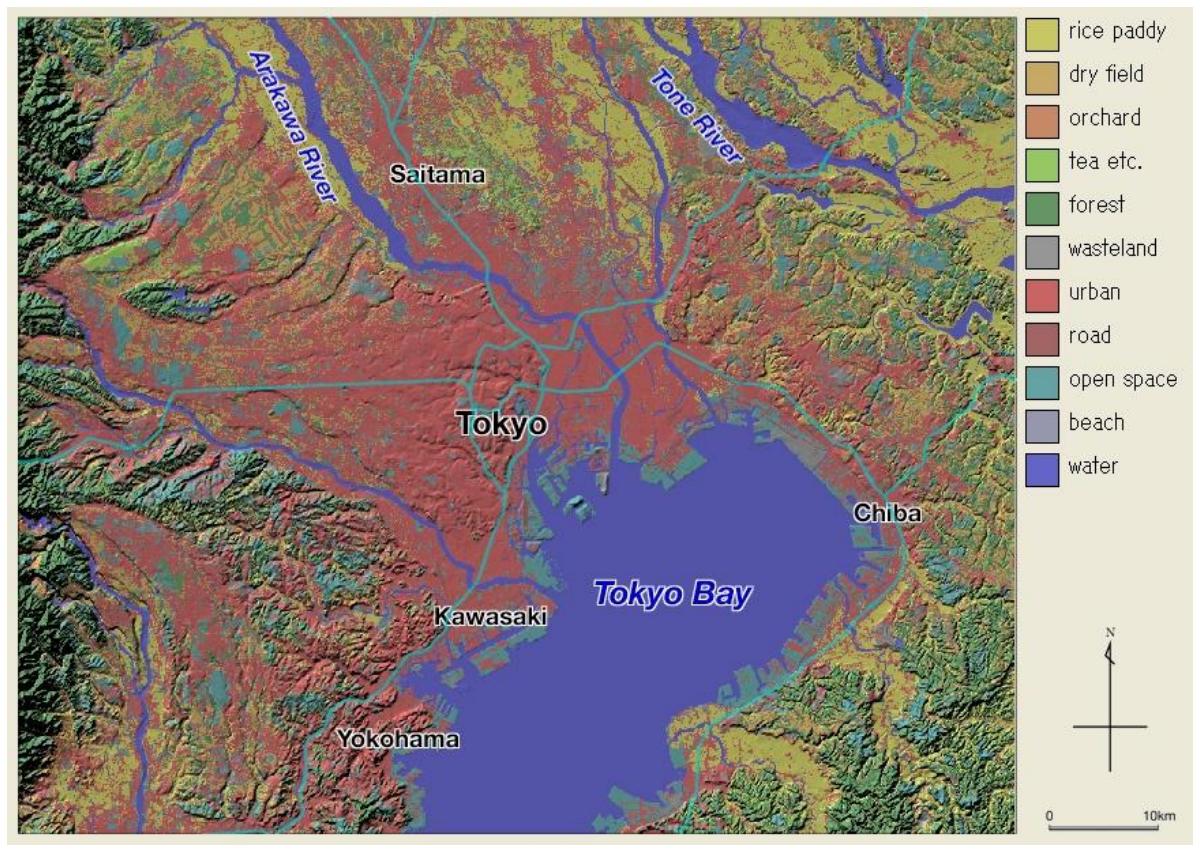

Figure 4 : Tokyo Land Use and Land Cover map.

(Source: http://www.hgeo.h.kyoto-u.ac.jp/ogata/mapRaster2/tokyo/index-e.html)

To deal with situation of flooding and exacerbating effect due to storm water runoff and torrential rains, the project conceived to build a underground infrastructure using five silos and through tunnels channel the overflow of water out of the city called as Metropolitan Area Outer Underground Discharge Channel or G-Cans project, which is the largest underground flood water diversion facility in the world (Bobylev, 2007). It is located in the outskirts of city between Showa in Tokyo and Kasukabe in Saitama prefecture and is an example of critical underground infrastructure of flood and storm water control management system. The figure showed, describe the wide network of tunnel to manage the storm water in the city and drain out the surface runoff out of the city.

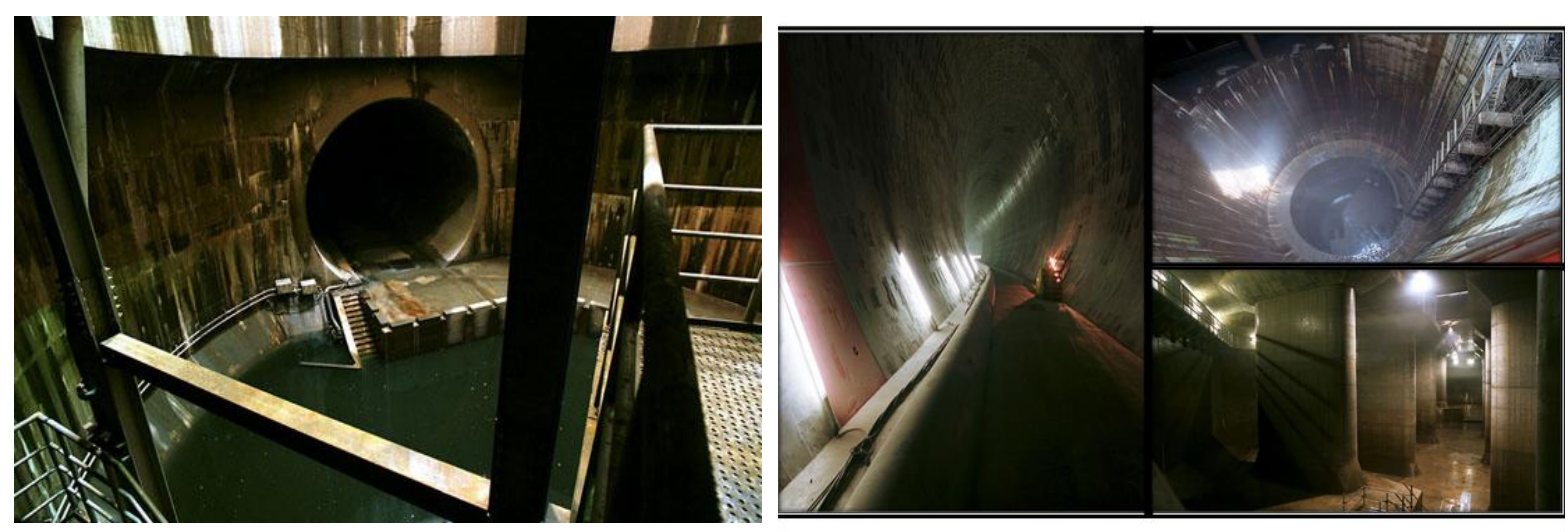

Figure 5a (left) and 5b (right): G-Cans Project Tokyo.

Figure 5 (a) and (b): Critical infrastructure-G-Cans, Tokyo is an underground infrastructure for prevention of flooding during rainy season, Source: G-Cans project, Tokyo (http://www.g-cans.jp/) 
The project comprises of $6.5 \mathrm{~km}$ long connecting tunnel, storage tank and around 78 pumps with five massive silos. There are five concrete containment silos which act as regulator, with the dimension of 65 meter deep by 32 meter in diameter and located limits from the rivers to connect to tunnel. The tunnel is constructed inside the ground around $50 \mathrm{~m}$ to send the water to the storage tank after overflow conditions. The storage tank, also known as underground temple $177 \mathrm{~m}$ long and $25 \mathrm{~m}$ high is supported by 59 pillars, $20 \mathrm{~m}$ taller. Another use of facility in dry season as it is open for tourists (G-Cans project, Tokyo).

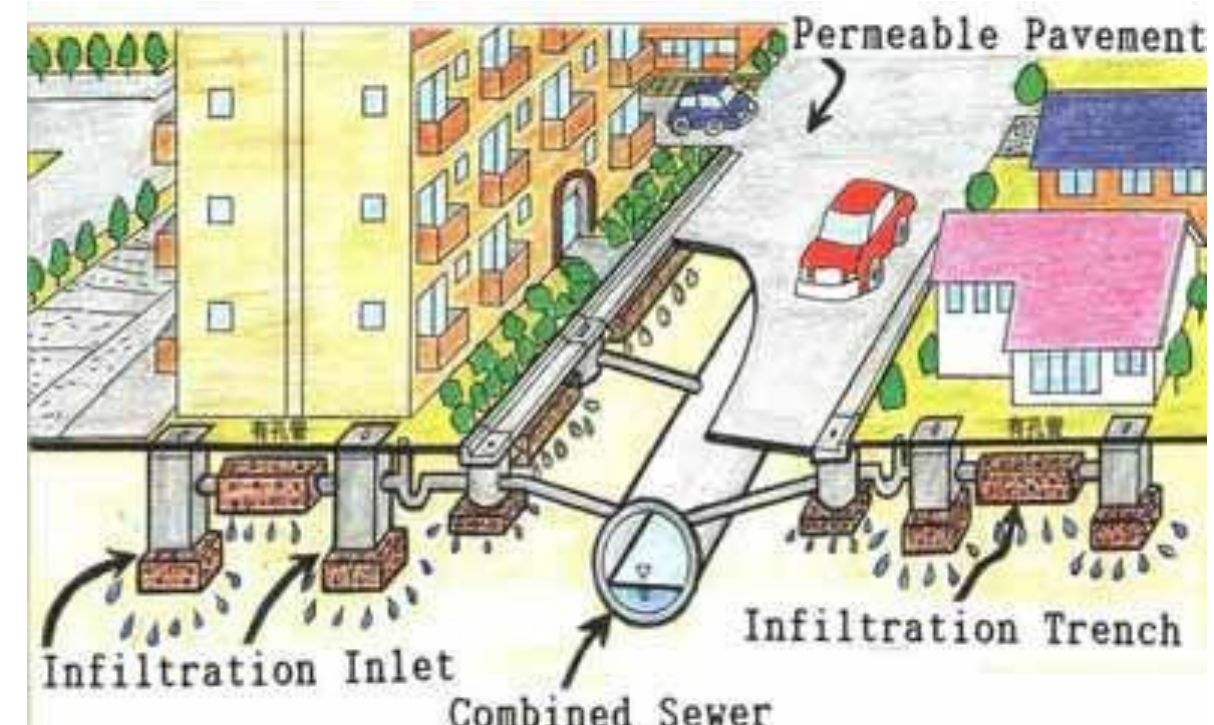

Figure 6: Inflitration trench and swerage system in Tokyo.

(Source:http://www.recwet.t.u-tokyo.ac.jp/furumailab/crest/workshop05/june9pm_2.pdf)

Another very popular and highly focused storm water control measure is artificial infiltration of storm water system in the city. Figure 6, showed the structure that permeable pavement, with house installed with facilities of artificial infiltration trench, which are connected to the combined sewer in case of over flow. In addition of flood prevention, this provides clean water environment and sound water cycle with recharging groundwater table, restore the spring water, disaster prevention and also preserving local ecosystem. The storm water runoff control management practices in Tokyo are focused and very effective in nature.

\section{Discussions}

Stormwater runoff management practices may be broadly classified in two categories in order to mitigate the negative impacts of storm water run-off. One is to reduce the surface water runoff quantity and another one is improving quality of storm water, before draining out in nearby water bodies or infiltrating in the ground. The storm water run-off management practices evolved with time and new strategies are developed to minimize the negative storm water runoff impacts, these strategies known as Low Impact Development (LID). It is a 
combination of sound site planning, structural techniques and nonstructural techniques (Dietz, 2007). LID techniques promoting the nature based designs, and interact with the processes to control storm water runoff, which provides measures to reduce the negative impact surface water runoff (Davis et al., 2005). Typical elements of conveyance are pavements, roofs, pipes and lawn area are helpful in designing. Studies from several years reveal that an increasing trend toward more sustainable practices and it is clear that conventional practices are not sustainable and cause environmental degradation shows a shift to LID or Best Management Practices to mitigate effects of Stormwater. The effective LID comprises of runoff mitigation measures that are part of larger group of strategies and practices in storm water management called as Best Management Practices or BMPs (Perez et al., 2005) and the combination of both called LID-BMPs which used low impact development based BMPs.

Non-structural BMPs comprises of practices such as reducing the disturbance in site, preserving the important features, less impervious cover, looking for vegetation option, more green places and also focusing on the natural drainage. Non-structural BMPs, generally classified in four category, such as landscaping and vegetation swales, minimizing the disturbance on site, management of impervious area and finally modification of time of storm water concentration. On the other hand, Structural BMPs perform very close to the runoff sources and used to control and treat runoff. Typical BMP, comprises of filters, surface devices located on individual lots in a residential commercial or industrial development area (Homer et al., 2001). Figure 7-8 explained and showed all the kind of structural BMPs. It include cisterns, rain barrels, vertical storage and devices which always used to capture rainwater and helpful in many sense from centuries. The use of cisterns are for holding larger volumes of water, approx 500 gallons or more, rain barrels normally collects the drainage from roof using pipes network and will be useful in small irrigation unit. The vertical storage are the stand along towers against a building to capture and storage. Another one is very interesting form called storage beneath structure, which store the storm water inside the structure (Guo et al., 2007). Another kind of storm water management policies are using the drainage system to take the storm water out of the city to the nearest water bodies, such as Japan built massive drainage structure. Above mentioned LID and BMPs techniques integration with bio-retention basins and structural BMPs are to applied as innovation in storm water management to improve quality of storm water. New paradigm of infiltration systems, bio-retention basins, and both surface and subsurface detention basins are together downsized to address storm water runoff close to its source. 


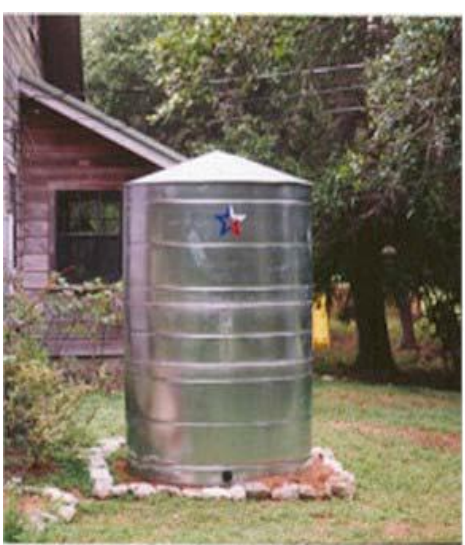

Figure 7 (a)

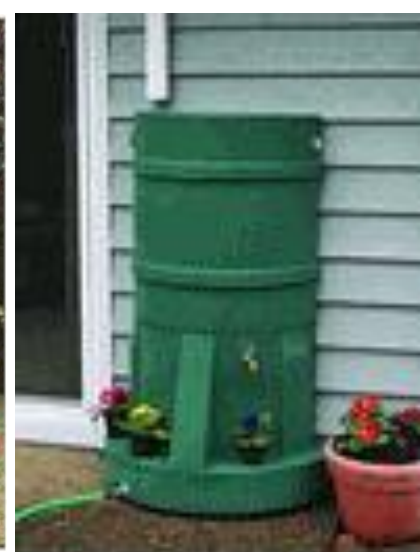

(b)

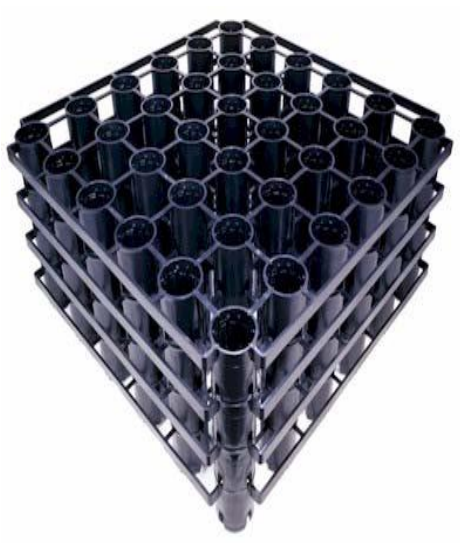

(c)

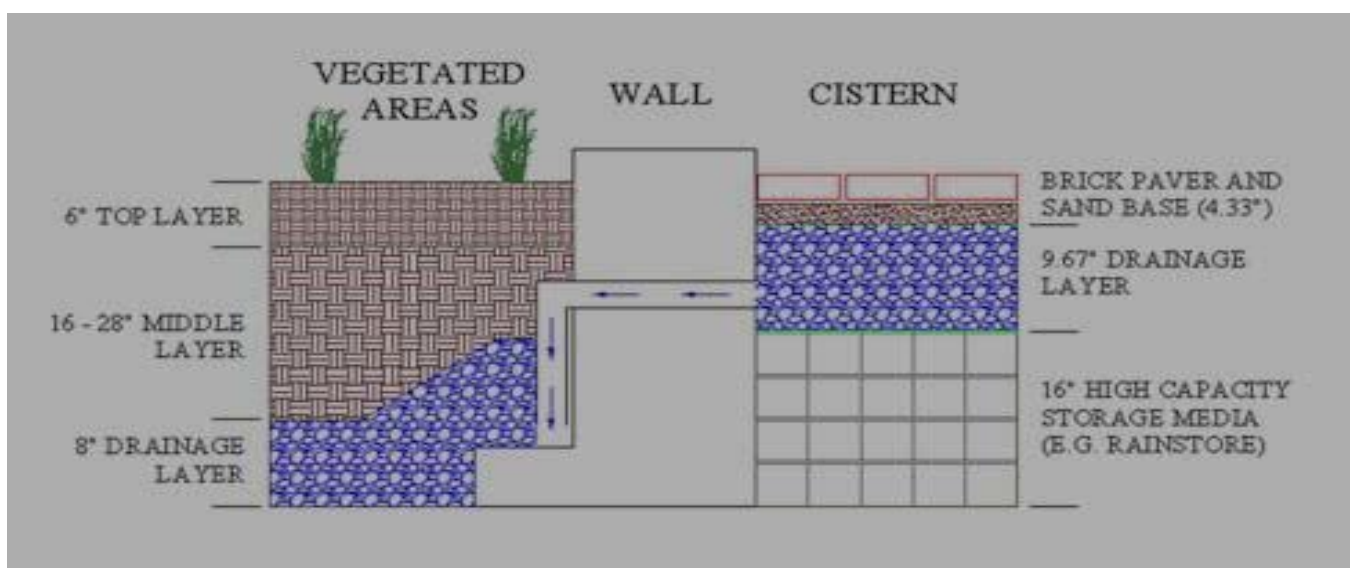

(d)

Figure 8: Structural Best Management Practices for storm water run-off management (a) Cisterns, (b) Rain Barrel, (c) Vertical Storage structures and (d) Storage beneath structure. (http://www.elibrary.dep.state.pa.us/dsweb/Get/Document-68001/6.5.2\%20BMP\%20Runoff $\% 20$ Capture\%20and\%20Reuse.pdf).

The green infrastructure is also the important part of management, as it is comprises of interconnected network natural areas as forests and wetlands that helps in improving water quality and helpful in providing recreational activities, wildlife, good air quality and urban heat island and other community acceptance. The important aspect of discussion here is community acceptance and governance for the storm water runoff management is equally important in this respect. Proper maintenance of storm water facilities can lead to reduced costs for stream channel restoration and pollution mitigation in the future. Ferguson (2005) described the conventional engineering methods to mitigate the effects of storm water, by quoting the oldest method of prime purpose of which is to reduce the nuisance of water that might collect by providing a smooth surface.

\section{Conclusions and Recommendations}

The storm water runoff management practices evolves through time, from conventional 
centralized system in past to low impact development and best management practices. It is still evolving and more innovative technologies like storm water artificial infiltration to ground, combination of LID and BMPs, structural and non-structural techniques, massive underground tunnels structures and use of nature based techniques are commonly used practices around the world and specifically the case study from Tokyo showed the effectiveness and efficiency of these practices. In the context of changing climate, it is necessary to manage the storm water runoff in efficient way and for the purpose numeric based computer simulation model are very helpful as study analyze comparatively the advantages and disadvantages. To understand the impact of climate change on hydrological cycle, assessment of local area and representing the result in digital or presentable format is easy with the use of advancement of GIS and remote sensing in the field. The paper also touched the method to assess the cost effectiveness of various storm water runoff management practices and explained the important factor behind the success as community acceptance. During the discussion in this paper, storm water governance structure is also analyzed and presented the relatively new and advantages storm water governance structure.

The important recommendation of the study is to understand the topographical features and lithological features, identification or demarcation of drainage areas and land use/land cover analysis of the flood prone areas will help to determine the runoff coefficient (Ouma et al., 2014). Also study of rainfall data, runoff coefficient and runoff data for at least last three decades will give a sound idea about the trend in the area of interest so that proper structural and nonstructural mitigation to be taken for storm water management. The estimation of carrying capacity and its structural stability using different methodology for the existing storm water drainage system and proper judgment of disposal place of storm water will be another useful tool for decision makers engaged in storm water management. The economic assessment for storm water management and its related damage reduction need to be judicially evaluated for their relative effectiveness in addressing the most critical problems unlike pumping huge money for programmatic component. Diligent regular monitoring before, during, and after project implementation can provide information to assess and improve project outcomes. More attention need to be paid for minimizing adverse effect of storm water on the ecological disturbance, estuarine damage, water quality degradation and the loss of natural resources rather than flooding and drainage problems which are catchy to our eyesight. However, this broader range of action warrants more legislative and community awareness well supported by pervious scientific studies (Bernadette et al., 2009).Understanding the economic environmental impacts through an integrated cost-benefit analysis in a socioeconomic context was analyzed by willingness to pay to avoid pollution. It may produce results that vary greatly from analysis of cost benefit analysis (Feng and Wang, 2007). 
There is also discussion about the preventive measures which are less expensive measures than restoration after storm water damages or treatment cost in urban areas, in addition the natural drainage preservations in local region and in the communities are benefits as open space to relax for citizens and staying near to nature (Karr and Rossano, 2001). The restoration of healthy, nature based areas are important for acceptance and for the potential for success and storm water programs requires detailed understanding of local environment to achieve success. The integral part of any storm water management practices is community acceptance and various studies showed that if community is more aware of advantages, maintenance and operations problems, they are more willing to contribute in any form, so it is vital to add community and citizens to be the as integral part of any new storm water management policies (Sohail et al., 2005).

\section{References}

Ashley, R.M., Balmforth, D.J., Saul, A.J. and Blanksby, J.R., (2005) Flooding in the future. Water Science and Technology, 52(5): 265-274.

Bernadette J., Derek B. Booth, and Anne C. Steinemann. "Costs and benefits of storm-water management: Case study of the Puget Sound region." Journal of Urban Planning and Development 135.4 (2009): 150-158.

Blair, A., Sanger, D., Holland, A. F., White, D., Vandiver, L. and White, S. (2010):Stormwater Runoff Modeling Impacts Of Urbanization And Climate Change, Proceedings of the South Carolina Water Resources Conference, October 13-14, 2010, the Columbia Metropolitan Convention Center (https://tigerprints.clemson.edu/cgi/viewcontent.cgi?article=1131\&context=scwrc, Accessed on December 14, 2019)

Bobylev, Nikolai. "Sustainability and vulnerability analysis of critical underground infrastructure." Managing Critical Infrastructure Risks. Springer Netherlands, 2007. 445-469.

Boller, M. "Towards sustainable urban stormwater management." Water Science and Technology: Water Supply 4.1 (2004): 55-65.

Calder, I.R., 2007. Forests and water - ensuring forest benefits outweigh water costs. For. Ecol. Manage. 251, 110-120.

Davis, Allen P., and Richard H. McCuen. Stormwater management for smart growth. Springer Science \& Business Media, 2005.

Dietz, Michael E. "Low impact development practices: A review of current research and recommendations for future directions." Water, air, and soil pollution 186.1-4 (2007): 351-363.

Dolnicar, Sara, and Anna Hurlimann. "Drinking water from alternative water sources: differences in beliefs, social norms and factors of perceived behavioural control across eight Australian locations." (2009): 1433.

Durrans, S.R. (2003) Stormwater Conveyance Modeling and Design. Waterbury, CT: Haestad Press. EPA (2007) Innovation and Research for Water Infrastructure for the 21st Century Research Plan, 
Environmental Protection Agency, Office of Research and Development, Washington DC, USA. Ferguson, Bruce K. Porous pavements. CRC Press, 2005.

Guo, Yiping, and Brian W. Baetz. "Sizing of rainwater storage units for green building applications." Journal of Hydrologic Engineering 12.2 (2007): 197-205.

Horner, Richard, et al. "Structural and non-structural BMPs for protecting streams." Linking stormwater BMP designs and performance to receiving water impact mitigation (2001): 60-77.

HUANG, Jin-liang, et al. "Characterization of surface runoff from a subtropics urban catchment." Journal of Environmental Sciences 19.2 (2007): 148-152.

Karr, J. R., and Rossano, E. M. 2001. "Applying public health lessons to protect river health.” Ecol. Civ. Eng., 41, 3-18.

Mitchell, V. G. and Diaper, C. (2005), UVQ: A tool for assessing the water and contaminant balance impacts of urban development scenarios, Water Science and Technology, 52(12): pp 91-98.

Ouma, Yashon O., and Ryutaro Tateishi. "Urban flood vulnerability and risk mapping using integrated multi-parametric AHP and GIS: Methodological overview and case study assessment." Water 6.6 (2014): 1515-1545.

Perez-Pedini, Cristina, James F. Limbrunner, and Richard M. Vogel. "Optimal location of infiltration-based best management practices for storm water management." Journal of water resources planning and management131.6 (2005): 441-448.

Ragab, R., J. Bromley, P. Rosier, J.D. Cooper and J.H.C. Gash (2003) Experimental study of water fluxes in a residential area: rainfall, roof runoff and evaporation. The effect of slope and aspect. Hydrological Processes. 17, 2409-2422.

Schueler, T. R. "Review of pollutant removal performance of stormwater ponds and wetlands." Watershed Protection Techniques 1.1 (1994): 17-18.

Sohail, M., Cavill, S., and Cotton, A. P. 2005. "Sustainable operation and maintenance of urban infrastructure: Myth or reality?” J. Urban Plann. Dev., 1311, 39-49.

SMDM (2018): Stormwater Management Design Manual, The City of Detroit Water and Sewerage Department

(https://detroitmi.gov/sites/detroitmi.localhost/files/2018-11/Stormwater\%20Mgmt\%20Design\%20M anual\%202018-11.pdf, Accessed on December 14, 20119)

Sundberg, C., G. Svensson, and Henriette Söderberg. "Re-framing the assessment of sustainable stormwater systems." Clean technologies and environmental policy 6.2 (2004): 120-127.

Takara, K., Tachikawa, Y., Kojima, T., et al., 2004. Flood controlfunction of mountain slopes covered with forests: quantitative assessment of the effects of so-called 'green dam' from the viewpoint of basin-scale hydrology. DisasterPrevention Research Institute Annuals, Kyoto University,171-182. 